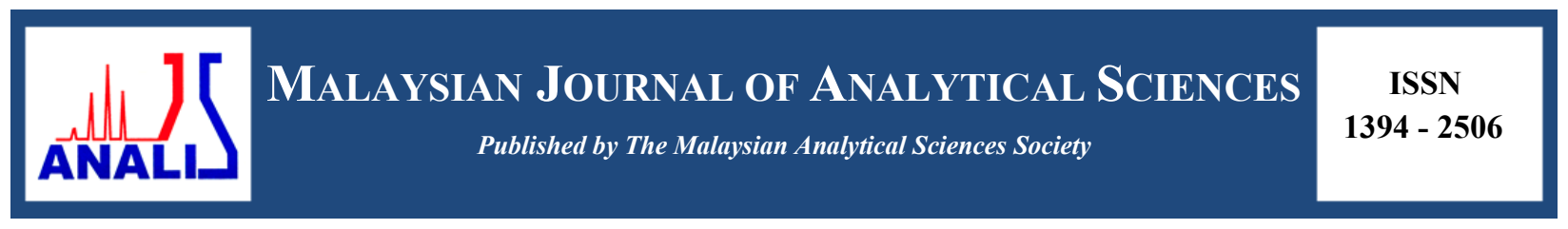

\title{
ONE-POT MANNICH BASE SYNTHESIS USING TASK SPECIFIC PROTIC IONIC LIQUIDS
}

\author{
(Sintesis Bes Mannich Tunggal Menggunakan Cecair Ionik Terkhusus) \\ Sabahat Sardar*, Cecilia Devi Wilfred, Jean Marc Leveque \\ Fundamental and Applied Sciences \\ Universiti Teknologi PETRONAS, Teronoh, Perak, Malaysia \\ *Corresponding author: sba.qau@gmail.com
}

Received: 21 August 2016; Accepted: 27 July 2017

\begin{abstract}
Three-component Mannich reaction of ketones, aromatic aldehydes and aromatic amines was catalyzed by four Bronsted acidic ionic liquids comprising of iodide and borate at room temperature. Ionic liquid have been used as catalyst and solvent to produce some Mannich bases in high yield (75\%) and shorter reaction time (20 minutes). Work up has been facilitated by simple extraction with water to recover ionic liquid for recycling up to four times without any significant loss in activity.
\end{abstract}

Keywords: Mannich bases, Bronsted acidic ionic liquids, 1-methylimidazole, 1,3-propane sultone, 1,4-butane sultone

Abstrak

Tindak balas tiga komponen Mannich iaitu keton, aldehid aromatik dan amina aromatik telah dimangkinkan oleh empat cecair ionik Bronsted berasid yang terdiri daripada iodida dan borat pada suhu bilik. Cecair ionik telah digunakan sebagai pemangkin dan pelarut untuk menghasilkan beberapa bes Mannich dengan hasil yang tinggi (75\%) dan masa tindak balas yang lebih pendek (20 minit). Kerja pengekstrakan telah dipermudah dengan menggunakan air dan boleh dikitar semula sehingga empat kali tanpa sebarang kehilangan aktiviti yang penting.

Kata kunci: bes Mannich, asid Bronsted cecair ionik, 1-metilimidazol, 1,3-propana sulton, 1,4-butana sulton

\section{Introduction}

Multicomponent reactions have been proven to be an economic and facile approach for building of complex molecules in one synthetic step. A remarkable diversity can be achieved by varying the starting materials. Such appealing reactions offer an elegant course for synthesis of carbon-carbon and carbon-hetero atom linkages with high atom economy, simple methodology and high selectivity in one-pot procedure [1]. Mannich reaction is a fundamental method for a formation of $\beta$-amino carbonyl compounds of synthetic intermediates for natural product synthesis (alkaloids and polyketides) and in pharmaceutical industry [2]. The conventional catalysts for the synthesis of classical Mannich bases are mainly organic and mineral acids such as acetic acid [3], proline [4], p-dodecylbenzenesulfonic acid [5] and lewis acids [6]. These reactions conditions often lead to problems like difficulty in product separation, harsh reaction conditions, long reaction durations, toxicity and pollution [7]. Further development lead to the usage of other catalysts such as pTSA, BDMS, $\mathrm{HClO}_{4}-\mathrm{SiO}_{2}, \mathrm{TMSCl}$, Amberlyst15, carbon based solid acid, $\mathrm{AuCl}_{3}-\mathrm{PPh}_{3}, \mathrm{InCl}_{3}$, silica supported sulphuric acid, $\mathrm{NbCl}_{5}$, bismuth (III) chloride, sulfamic acid, boric acid, sucrose charsulfunic acid, $\mathrm{Zn}(\mathrm{OTf})_{2}$, etc. [8]. The drawbacks include: large amount of 
catalyst, expensive catalyst, high waste production, long reaction duration and ultimately low yield. [9]. Lanthanide triflate in acetonitrile or dichloromethane has also been reported for Mannich reaction catalysis [10].

In contribution to green chemistry, many studies reported on employing traditional volatile and flammable solvents to benign alternatives such as non-volatile solvent, supercritical system, aqueous media or solventless conditions. In this context, Mannich type reactions have also been reported in water [10]. In current years, ionic liquids (ILs) have been used as an environmentally benign solvents, efficient catalysts and a promising substitutes for volatile organic solvents and traditionally used acid/ base catalysts in construction of organic moieties $[11,12]$. Use of organic solvents in reaction mixture usually leads to serious safety issues such as volatility, flammability and toxicity [12, 13]. The use of ionic liquids as reaction media offers a convenient solution to both solvent emission and catalytic recycling problems [10]. Beside high activity and selectivity, these versatile liquids are center of interest as they possess unique properties such as flexibility, high stability in air and water, easy separation and purification processes, reusability, non-volatility, non-flammability, noncorrosive nature, controlled immiscibility, low toxicity, low vapour pressure, low viscosities, high thermal and chemical stabilities [14-16]. Recently work on Mannich reaction is being carried out using ionic liquids $[17,18]$.

The present study emphasizes on employing ionic liquids as catalyst and solvents to overcome issues associated with traditional catalysts and organic solvents. In this approach, a green procedure has been proposed for synthesis of Mannich bases using acetophenone, aromatic aldehydes and anilines as starting materials. To the best of our knowledge, Mannich reaction catalyzed by ILs bearing imidazolium sultone as cation; and iodide and borate as anions are unprecedented. The reaction proceeded at faster rate with higher yield of desired Mannich bases using the synthesized ionic liquids. The effect of cations and anions in addition to the influence of additional carbon atom on sultone moiety was also been investigated.

\section{Chemicals}

\section{Materials and Methods}

All the reacting molecules used such as 1,3-propane sultone, 1,4-butane sultone, $N$-methylimidazole, hydriodic acid, boric acid, acetonitrile, aromatic amines, aromatic aldehydes, acetophenone and cyclohexanone were purchased from Sigma Aldrich and used without any purification procedure. Melting points of the Mannich bases were determined in open capillaries and are uncorrected. NMR spectra were recorded on $400 \mathrm{MHz} \mathrm{NMR}$ Joel spectrometer using $\mathrm{D}_{2} \mathrm{O}$ and $\mathrm{CDCl}_{3}$ as solvents. IR spectra were recorded in Nicolet FTIR spectrometer $(400-4000$ $\left.\mathrm{cm}^{-1}\right)$.

\section{Synthesis of ionic liquids}

The task specific ionic liquids have been synthesized by using an analogous method as reported in literature [19-21] with slight modifications. 1,3-propane sultone and 1,4-butane sultone were reacted with $N$-methylimidazole in equimolar ratio affording the respective zwitter ions that were then converted to ILs by acidification with two protic acids (Scheme 1). The corresponding ILs were used further without any purification.

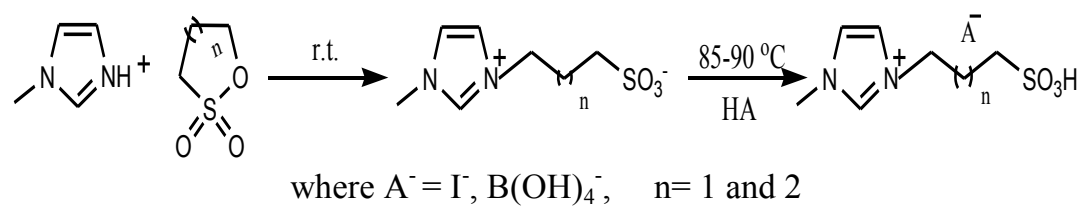

Scheme 1. Reaction scheme for IL synthesis

\section{Mannich reaction: A typical procedure}

Cyclohexanone $(10 \mathrm{mmol})$, benzaldehyde $(10 \mathrm{mmol})$, aniline $(10 \mathrm{mmol})$ and $5 \mathrm{mmol}$ of catalyst were taken in round bottom flask at $25{ }^{\circ} \mathrm{C}$ (Scheme 2) [22]. The completion of reaction was determined using TLC. For work up, some amount of water was added and extraction with ethyl acetate was done. The excess solvent was evaporated via rotary evaporator to afford solid product which was recrystallized from acetonitrile and dried under vacuum until 
constant weight was obtained. At the end, the aqueous layer containing IL was vacuum dried at $70{ }^{\circ} \mathrm{C}$ to reuse ionic liquid for future use. The synthesized compounds were then characterized using IR and NMR. The spectral analysis along with physical data (melting points) was consistent with those reported in literature.

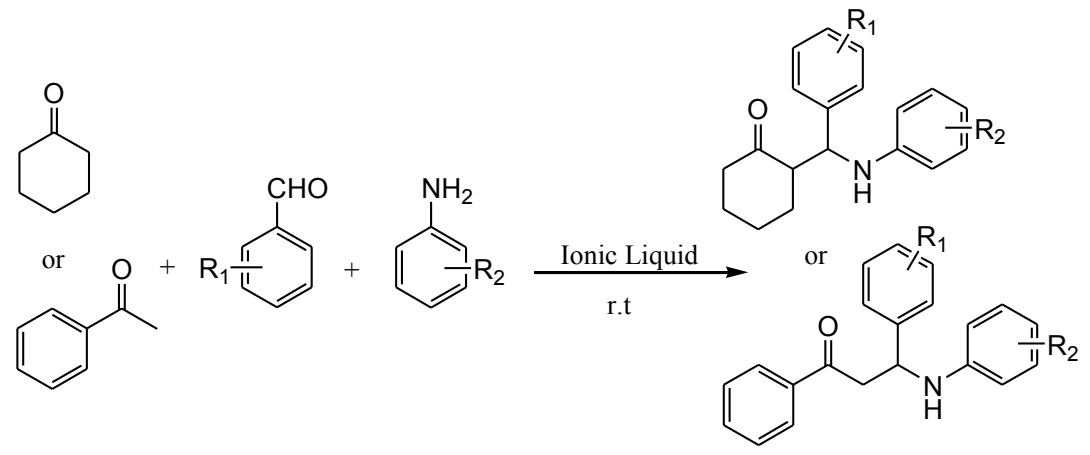

Scheme 2. Mannich reaction catalyzed by imidazolium based ionic liquids $\left(\mathrm{R}_{1}\right.$ and $\mathrm{R}_{2}$ are mentioned in Table 4$)$

\section{Results and Discussion}

The ionic liquids were synthesized by the reaction of methyl imidazole with 1,3-propane sultone and 1,4-butane sultone for preparation of Mannich bases. Spectral analysis confirmed the structure of synthesized ILs. these synthesized ILs were used to catalyze Mannich reaction using acetophenone/ cyclohexanone (10 mmol), benzaldehyde $(10 \mathrm{mmol})$ and aniline $(10 \mathrm{mmol})$ as model substrates at room temperature (Scheme 2$)$.

The reaction mixture gradually turned to highly viscous material within 30 minutes. The reaction work up was done by addition of a small amount of water followed by extraction with ethyl acetate and finally evaporation of organic solvent. For purification, the synthesized Mannich bases were recrystallized from acetonitrile and the aqueous layer was further dried for recycling ionic liquid. Among the four protic ILs 75\% of Mannich base was obtained as highest yield by 1-methyl-3-(3-sulfopropyl)-imidazolium borate ([mimps]HBO) in 20 minutes (Table 1).

Table 1. Effect of ionic liquid on yield of Mannich base ${ }^{a}$

\begin{tabular}{|c|c|c|c|c|}
\hline Entry & Catalyst & Solvent Used & $\begin{array}{l}\text { Reaction Time } \\
(\text { min) }\end{array}$ & $\begin{array}{c}\text { Isolated Yield } \\
(\%)\end{array}$ \\
\hline 01 & - &,$- \mathrm{EtOH}^{\mathrm{b}, \mathrm{c}, \mathrm{d}}$ & 120 & $\mathrm{NR}^{\mathrm{a}, \mathrm{b}, \mathrm{c}, \mathrm{d}}$ \\
\hline 02 & [mimps]I &,$- \mathrm{EtOH}^{\mathrm{b}, \mathrm{c}, \mathrm{d}}$ & 120 & $\mathrm{NR}^{\mathrm{a}, \mathrm{b}, \mathrm{c}, \mathrm{d}}$ \\
\hline 03 & {$[\mathrm{mimbs}] \mathrm{I}$} &,$- \mathrm{EtOH}^{\mathrm{b}, \mathrm{c}, \mathrm{d}}$ & 120 & $\mathrm{NR}^{\mathrm{a}, \mathrm{b}, \mathrm{c}, \mathrm{d}}$ \\
\hline 04 & [mimps]HBO & - & 20 & 75 \\
\hline 05 & [mimbs]HBO & - & 30 & 69 \\
\hline
\end{tabular}

The reaction with $\mathrm{I}^{-}$as anion, was also carried out with ethanol using same IL as catalyst using different temperatures but the results obtained were insignificant (Table 1). It was observed that IL based on propane sultone gave better yield than butane sultone based IL (entries 4 and 5 in Table 1). Furthermore it was also found that the IL formed from weak acid $\left(\mathrm{H}_{3} \mathrm{BO}_{3}\right)$ gave better yield as compared to the IL which was formed from strong acid (HI). 
This observation might be rationalized on basis of $\mathrm{pKa}$, which depicts that the reaction is catalyzed by conjugate bases $\left(\mathrm{I}^{-}\right.$and $\left.\mathrm{B}(\mathrm{OH})_{4}^{-}\right)$of the protic acids $\left(\mathrm{HI}\right.$ and $\left.\mathrm{H}_{3} \mathrm{BO}_{3}\right)$.

For determining the amount of IL used, the reaction of cyclohexanone $(10 \mathrm{mmol})$, benzaldehyde $(10 \mathrm{mmol})$, aniline $(10 \mathrm{mmol})$ was catalyzed under variable amounts of [mimps]HBO at room temperature. It was found that the yields of the Mannich base was increased with the increase in the amount of [mimps]HBO (Table 2), where 5 mmol was found as an optimal amount.

Table 2. Effect of amount of ionic liquid on Mannich reaction

\begin{tabular}{lccc}
\hline Entry & $\begin{array}{c}\text { Ionic Liquid } \\
(\mathbf{m m o l})\end{array}$ & $\begin{array}{c}\text { Reaction Time } \\
(\mathbf{m i n})\end{array}$ & $\begin{array}{c}\text { Isolated Yield } \\
\mathbf{( \% )}\end{array}$ \\
\hline 01 & 0 & $24 \mathrm{~h}$ & 0 \\
02 & 1 & 30 & 66 \\
03 & 3 & 30 & 71 \\
04 & 5 & 30 & 75 \\
05 & 7 & 30 & 74 \\
06 & 9 & 30 & 75 \\
\hline
\end{tabular}

Mannich reaction was also conducted in polar and non-polar organic solvents to check the effect of solvent on the yield of product formed for estimation of the best reaction conditions. Herein the reaction of cyclohexanone, benzaldehyde and aniline was selected as standard reaction. It was found that the reaction in which no solvent was used gave the highest yield of $75 \%$ among the solvents selected showing that the ionic liquid may act as dualreagent without need of any external solvent (Table 3).

Table 3. Effect of ionic liquid/solvent on Mannich reaction ${ }^{\mathrm{a}}$

\begin{tabular}{|c|c|c|}
\hline Entry & Ionic Liquid/Solvent & Isolated Yield \\
\hline 01 & [mimps]HBO & 75 \\
\hline 02 & {$[\mathrm{mimps}] \mathrm{HBO} / \mathrm{H}_{2} \mathrm{O}$} & 70 \\
\hline 03 & {$[\mathrm{mimps}] \mathrm{HBO} / \mathrm{C}_{2} \mathrm{H}_{5} \mathrm{OH}$} & 69 \\
\hline 04 & [mimps] $\mathrm{HBO} / \mathrm{CH}_{2} \mathrm{Cl}_{2}$ & 61 \\
\hline 05 & {$[\mathrm{mimps}] \mathrm{HBO} / \mathrm{C}_{6} \mathrm{H}_{6}$} & 39 \\
\hline
\end{tabular}

The Mannich reaction was further investigated with different aromatic aldehydes and anilines using [mimps]HBO. It was observed that aromatic aldehyde with electron-donating group produced higher yield of Mannich base as compared to that of electron withdrawing group (Table 4). In case of aromatic anilines, both electron withdrawing and electron-donating groups have been reported to be equally valuable for Mannich reaction [7]. The synthesis of Mannich bases was confirmed by physical and spectroscopic data and was found in good agreement with the previous reports. 
Table 4. Preparation of -amino ketones using [mimps]HBO as catalyst

\begin{tabular}{|c|c|c|c|c|c|c|}
\hline Entry & $\mathbf{R}_{1}$ & $\mathbf{R}_{\mathbf{2}}$ & $\begin{array}{l}\text { H-Active } \\
\text { Molecule }\end{array}$ & Product & $\begin{array}{c}\text { Yield } \\
(\%)\end{array}$ & $\begin{array}{c}\operatorname{mp}\left({ }^{\circ} \mathrm{C}\right) \\
\text { (lit. } \mathrm{mp}) \text { [ref] }\end{array}$ \\
\hline 01 & $\mathrm{H}$ & $\mathrm{H}$ & $\left(\mathrm{CH}_{2}\right)_{5} \mathrm{CO}$ & & 75 & $\begin{array}{c}114-115 \\
(115-116)[24]\end{array}$ \\
\hline 02 & 4-chloro & $\mathrm{H}$ & $\left(\mathrm{CH}_{2}\right)_{5} \mathrm{CO}$ & & 73 & $\begin{array}{c}133-134 \\
(134-135)[25]\end{array}$ \\
\hline 03 & $\mathrm{H}$ & $\mathrm{H}$ & $\mathrm{C}_{6} \mathrm{H}_{5} \mathrm{CO}$ & & 75 & $\begin{array}{c}168-169 \\
(169-171)[26]\end{array}$ \\
\hline 04 & 4-methoxy & $\mathrm{H}$ & $\mathrm{C}_{6} \mathrm{H}_{5} \mathrm{CO}$ & & 74 & $\begin{array}{c}150-151 \\
151-152[27]\end{array}$ \\
\hline 05 & $\mathrm{H}$ & $4-\mathrm{NO}_{2}$ & $\mathrm{C}_{6} \mathrm{H}_{5} \mathrm{CO}$ & & 72 & $\begin{array}{c}184-186 \\
183-185[27]\end{array}$ \\
\hline
\end{tabular}

Regarding the reusability of ionic liquid, it was found that the IL could be successfully reused up to four cycles without considerable loss of activity (Table 5).

Table 5. Reusability of $[$ mimps $] \mathrm{CH}_{3} \mathrm{COO}$ for Mannich reaction

\begin{tabular}{llc}
\hline Entry & Cycle & \% Yield \\
\hline 1 & I & 75 \\
2 & II & 75 \\
3 & III & 74 \\
4 & IV & 74 \\
\hline
\end{tabular}

Spectral analyses of Zwitter ions and ionic liquids: 1-methylimidazolium-3-(3-propylsulfonate)

${ }^{1} \mathrm{H}$ NMR (400 MHz, $\left.\mathrm{D}_{2} \mathrm{O}\right): \delta(\mathrm{ppm}) 2.24(2 \mathrm{H}, \mathrm{m}), 2.73(2 \mathrm{H}, \mathrm{t} J=7.32 \mathrm{~Hz}), 3.92(3 \mathrm{H}, \mathrm{s}), 4.24(2 \mathrm{H}, \mathrm{t} J=7.24 \mathrm{~Hz}), 7.37$ $(1 \mathrm{H}, \mathrm{s}), 7.45(1 \mathrm{H}, \mathrm{s}), 8.87(1 \mathrm{H}, \mathrm{s}) ;{ }^{13} \mathrm{C} \mathrm{NMR}\left(400 \mathrm{MHz}, \mathrm{D}_{2} \mathrm{O}\right): \delta(\mathrm{ppm}) 25.5\left(\mathrm{CH}_{3}\right), 38.7\left(\mathrm{CH}_{2}\right), 48.2\left(\mathrm{CH}_{2}\right), 49.5$ $\left(\mathrm{CH}_{2}\right), 124.1(\mathrm{C}=\mathrm{C}), 126.3(\mathrm{C}=\mathrm{C}), 139.1(\mathrm{C}=\mathrm{N}) ; \mathrm{IR}\left(\mathrm{cm}^{-1}\right)$ : $3093 \mathrm{C}-\mathrm{H}$ stretching (alkene), $1654 \mathrm{C}=\mathrm{N}$ stretching (imine), $1456 \mathrm{CH}_{2}$ bending, 1178 and $1158 \mathrm{~S}=\mathrm{O}$ stretching (sulfonate), $1034 \mathrm{~S}=\mathrm{O}$ stretching (sulfoxide).

\section{1-methyl-3-(3-sulfopropyl)-imidazolium iodide}

([mimps]I, Table 2, entry 2): ${ }^{1} \mathrm{H}$ NMR (400 MHz, $\left.\mathrm{D}_{2} \mathrm{O}\right): \delta(\mathrm{ppm}) 2.18(2 \mathrm{H}, \mathrm{m}), 2.78(2 \mathrm{H}, \mathrm{t} J=7.23 \mathrm{~Hz}), 3.75(3 \mathrm{H}, \mathrm{s})$, $4.22(2 \mathrm{H}, \mathrm{t}), 6.37(1 \mathrm{H}, \mathrm{s}), 6.45(1 \mathrm{H}, \mathrm{s}), 7.67(1 \mathrm{H}, \mathrm{s}) ;{ }^{13} \mathrm{C}$ NMR $\left(400 \mathrm{MHz}, \mathrm{D}_{2} \mathrm{O}\right): \delta(\mathrm{ppm}) 22.9\left(\mathrm{CH}_{3}\right), 37.9\left(\mathrm{CH}_{2}\right)$, $50.4\left(\mathrm{CH}_{2}\right), 56.8\left(\mathrm{CH}_{2}\right), 122.9(\mathrm{C}=\mathrm{C}), 123.1(\mathrm{C}=\mathrm{C}), 137.2(\mathrm{C}=\mathrm{N}) ; \mathrm{IR}\left(\mathrm{cm}^{-1}\right): 3090 \mathrm{C}-\mathrm{H}$ stretching (alkene), 1685 $\mathrm{C}=\mathrm{N}$ stretching (imine), $1560 \mathrm{C}=\mathrm{C}$ stretching (cyclic alkene), $1453 \mathrm{CH}_{2}$ bending, $1160 \mathrm{~S}=\mathrm{O}$ stretching (sulfonate), $1020 \mathrm{~S}=\mathrm{O}$ stretching (sulfoxide). 
1-methyl-3-(4-sulfobutyl)-imidazolium iodide

([mimbs]I, entry 3): ${ }^{1} \mathrm{H}$ NMR $\left(400 \mathrm{MHz}, \mathrm{D}_{2} \mathrm{O}\right): \delta(\mathrm{ppm}) 1.61(2 \mathrm{H}, \mathrm{m}), 1.88(2 \mathrm{H}, \mathrm{m}), 2.81(2 \mathrm{H}, \mathrm{t} J=6.98 \mathrm{~Hz}), 3.73$

$(3 \mathrm{H}, \mathrm{s}), 4.12(2 \mathrm{H}, \mathrm{t} J=6.86 \mathrm{~Hz}), 7.32(1 \mathrm{H}, \mathrm{s}), 7.38(1 \mathrm{H}, \mathrm{s}), 8.61(1 \mathrm{H}, \mathrm{s}) ;{ }^{13} \mathrm{C}$ NMR $\left(400 \mathrm{MHz}, \mathrm{D}_{2} \mathrm{O}\right): \delta(\mathrm{ppm}) 21.3$ $\left(\mathrm{CH}_{3}\right), 28.2\left(\mathrm{CH}_{2}\right), 37.7\left(\mathrm{CH}_{2}\right), 52.1\left(\mathrm{CH}_{2}\right), 57.6\left(\mathrm{CH}_{2}\right), 122.6(\mathrm{C}=\mathrm{C}), 122.8(\mathrm{C}=\mathrm{C}), 137.4(\mathrm{C}=\mathrm{N}) ; \mathrm{IR}\left(\mathrm{cm}^{-1}\right): 3090 \mathrm{C}-$ $\mathrm{H}$ stretching (alkene), $1685 \mathrm{C}=\mathrm{N}$ stretching (imine), $1560 \mathrm{C}=\mathrm{C}$ stretching (cyclic alkene), $1453 \mathrm{CH}_{2}$ bending, 1161 $\mathrm{S}=\mathrm{O}$ stretching (sulfonate), $1020 \mathrm{~S}=\mathrm{O}$ stretching (sulfoxide).

1-methyl-3-(3-sulfopropyl)-imidazolium borate

([mimps]HBO, entry 4): ${ }^{\mathrm{l}} \mathrm{H}$ NMR $\left(400 \mathrm{MHz}, \mathrm{D}_{2} \mathrm{O}\right): \delta(\mathrm{ppm}) 2.19(2 \mathrm{H}, \mathrm{m}), 2.78(3 \mathrm{H}, \mathrm{s}), 3.75(2 \mathrm{H}, \mathrm{t} J=7.24 \mathrm{~Hz})$, $4.23(2 \mathrm{H}, \mathrm{t} J=7.16 \mathrm{~Hz}), 7.32(1 \mathrm{H}, \mathrm{s}), 7.38(1 \mathrm{H}, \mathrm{s}), 8.61(1 \mathrm{H}, \mathrm{s}) ;{ }^{13} \mathrm{C}$ NMR $\left(400 \mathrm{MHz}, \mathrm{D}_{2} \mathrm{O}\right): \delta(\mathrm{ppm}) 23.6\left(\mathrm{CH}_{3}\right)$, $36.3\left(\mathrm{CH}_{2}\right), 50.3\left(\mathrm{CH}_{2}\right), 56.5\left(\mathrm{CH}_{2}\right), 121.2(\mathrm{C}=\mathrm{C}), 121.5(\mathrm{C}=\mathrm{C}), 137.5(\mathrm{C}=\mathrm{N})$; IR $\left(\mathrm{cm}^{-1}\right)$ : $3159 \mathrm{C}-\mathrm{H}$ stretching (alkene), $1640 \mathrm{C}=\mathrm{N}$ stretching (imine), $1574 \mathrm{C}=\mathrm{C}$ stretching (cyclic alkene), 1392, $1163 \mathrm{~S}=\mathrm{O}$ stretching (sulfonate), $1035 \mathrm{~S}=\mathrm{O}$ stretching (sulfoxide).

1-methyl-3-(4-sulfobutyl)-imidazolium borate

([mimbs]HBO, entry 5): ${ }^{1} \mathrm{H}$ NMR $\left(400 \mathrm{MHz}, \mathrm{D}_{2} \mathrm{O}\right): \delta(\mathrm{ppm}) 1.61(2 \mathrm{H}, \mathrm{m}), 1.91(2 \mathrm{H}, \mathrm{m}), 2.82(2 \mathrm{H}, \mathrm{t} J=7.24 \mathrm{~Hz})$, $3.78(3 \mathrm{H}, \mathrm{s}), 4.14(2 \mathrm{H}, \mathrm{t} J=7.31 \mathrm{~Hz}), 7.35(1 \mathrm{H}, \mathrm{s}), 7.41(1 \mathrm{H}, \mathrm{s}), 8.61(1 \mathrm{H}, \mathrm{s}) ;{ }^{13} \mathrm{C}$ NMR $\left(400 \mathrm{MHz}, \mathrm{D}_{2} \mathrm{O}\right): \delta(\mathrm{ppm})$ $20.03\left(\mathrm{CH}_{3}\right), 27.2\left(\mathrm{CH}_{2}\right), 36.9\left(\mathrm{CH}_{2}\right), 47.9\left(\mathrm{CH}_{2}\right), 49.2\left(\mathrm{CH}_{2}\right), 121.8(\mathrm{C}=\mathrm{C}), 122.6(\mathrm{C}=\mathrm{C}), 136.3(\mathrm{C}=\mathrm{N}) ; \mathrm{IR}\left(\mathrm{cm}^{-1}\right)$ : $3157 \mathrm{C}-\mathrm{H}$ stretching (alkene), $1641 \mathrm{C}=\mathrm{N}$ stretching (imine), $1575 \mathrm{C}=\mathrm{C}$ stretching (cyclic alkene), $1165 \mathrm{~S}=\mathrm{O}$ stretching (sulfonate), $1038 \mathrm{~S}=\mathrm{O}$ stretching (sulfoxide).

\section{Conclusion}

Present methodology deals with a useful and effective way for synthesis of Mannich bases at room temperature in short reaction duration (20 minutes) and good yield (75\%) using ILs as dual reagents. The reported synthetic method can be expected as an environmentally green procedure that might give valuable organic transformations by substituting conventional volatile, toxic and flammable organic solvents with ILs. Simple experimental and work up conditions along with reusability of IL can contribute a new method of green chemistry concept.

\section{References}

1. Mukhopadhyay, C., Rana, S. and Butcherb, R. J. (2010). An ionic liquid $\left\{[\text { secbmim }]^{+} \mathrm{Br}^{-}\right\}$as a "dual reagent catalyst" for the multicomponent synthesis of (quinilinyl- and isoquinolinyl- amino) alkylnaphthols, their bisanalogs and a facile route to naphthoxazines. ARKIVOC, 10: $291-304$.

2. Balasubramaniam, S. and Aidhen, I. S. (2008). The growing synthetic utility of the weinreb amide, Synthesis, 2008(23): 3707 - 3738.

3. Mogilaiah, K. and Kanksiah, G. (2002). Synthesis and antibacterial activity of novel Mannich bases containing 1,8-naphthyridine moiety. Indian Journal Heterocyclic Chemistry, 11: 282 - 286.

4. List, B. (2000). The direct catalytic asymmetric three-component Mannich reaction. Journal of American Chemical Society, 122: 9336 - 9338.

5. Manabe, K., Mori, Y and Kobayashi, S. (2001). Three-component carbon-carbon bond-forming reactions catalyzed by a Bronsted acid-surfactant-combined catalyst in water. Tetrahedron, 57: $2537-2544$.

6. Kobayashi, S., Hamada, T. and Manabe, K. (2002). The catalytic asymmetric Mannich type reactions in aqueous media. Journal of American Chemical Society, 124: 5640 - 5641.

7. Zhao, G. and Lu, M. (2012). One-pot green procedure for Mannich reaction catalyzed by task specific ionic liquid. Chiang Mai Journal of Science, 39: 49 - 58.

8. Vadivel, P., Maheswari, C. S. and Lalitha, A. (2013). Synthesis of $\beta$-amino carbonyl compounds via Mannich reaction using sulfated MCM-41. International Journal of Innovative Technology and Exploring Engineering, 2: $2278-3075$.

9. Hajipoura, A. R. and Rafieeb, F. (2009) Basic ionic liquids. A short review. Journal of the Iranian Chemical Society, 6: $647-678$.

10. Sahoo, S. Joseph, T. and Halligudi, S. B. (2006). Mannich reaction in Bronsted acidic ionic liquids: A facile synthesis of $\beta$-amino carbonyl compounds. Journal of Molecular Catalysis A: Chemical, 244: 179 - 182. 
11. Cole, A. C. Jensen, J. L. Ntai, L. Loan, K. and Forbes, D. C. (2002). Novel Bronsted acidic ionic liquids and their use as dual solvent-catalyst. Journal of American Chemical Society, 124: 5962 - 5963.

12. Sapkal, S. B. Shelke, K. F. Madje, B. R. Shingate, B. B. and Shingare, M. S. (2009). 1-butyl-3methyl imidazolium hydrogen sulphate promoted one-pot three-component synthesis of amidoalskyl naphthols. Bulletin Korean Chemical Society, 30: 2887 - 2889.

13. Rajendran, A. and Priyadarshini, M. (2010). Synthesis and characterization of a novel ionic liquid (TBAAMPS) and its applications in Mannich condensation reactions under solvent free conditions. African Journal of Pure and Applied Chemistry, 4: $183-187$.

14. Dyson, P. J. and Geldbach, T. J. (2007). Applications of ionic liquids in synthesis and catalysis. The Electrochemical Society Interface, 16(1): 50 - 53.

15. Cserjesi, P., Bako K. B. and Gubicza, N. (2008). Recent trends on application of ionic liquids in organic synthesis. Hungarian Journal of Industrial Chemistry, 36: 27 - 34.

16. Rajendran, A., Ramu, S. and Karthikeyan, C. (2011). Green synthesis of some novel N-Mannich bases using environmentally benign catalyst under solvent free conditions. International Journal of Current Research, 33: $161-167$.

17. Qain, H., Kai, W. and Zhen, J. (2016). Ultrasound-promoted synthesis of $\beta$-amino carbonyl coumpounds via a Mannich reaction catalyzed by ionic liquids. Letters in Organic Chemistry, 13: 143 - 147.

18. Senepak, W., Saeeng, R., Jaratiaroonphong, J., Kasemul, T. and Sirion, U. (2015). Green synthesis of dipyyromethanes in aqueous media catalyzed by $\mathrm{SO}_{3} \mathrm{H}$-funtionalized ionic liquids. Organic \& Biomolecular Chemistry, 14: $1302-1310$.

19. Kundamudi, K. Elavarasan, P. and Dyson, P. J (2010). Alkylation of p-cresol with tert-butyl alcohol using benign Bronsted acidic ionic liquid catalyst. Journal of Molecular Catalysis, 321: $34-41$.

20. Han, X. and Zhou, L. (2011). Optimization of process variables in the synthesis of butyl butyrate using acid ionic liquid as catalyst. Journal of Chemical Engineering, 172: 459 - 466.

21. Dubreuil, J. Bourahla, K. and Rahmouni, M. (2002). Catalyzed esterifications in room temperature ionic liquids with acidic counteranion as recyclable reaction media. Catalysis Communications, 3: 185-190.

22. Zahao, G., Jiang, T., Gao, H., Han, B., Haung, J. and Sun, D. (2004). Mannich reaction using acidic ionic liquids as catalysts and solvents. Green Chemistry, 6(2): $75-77$.

23. Suryawanshi, N. S., Jain, P., Singhal M. and Khan, I. (2012). Mannich synthesis under ionic liquid [Et3NH][HSO4] catalysis. IOSR Journal of Applied Chemistry 1: 18 - 23.

24. Yang, Y. Y., Shou, W. G. and Wang, Y. G. (2006). Synthesis of $\beta$-amino carbonyl compounds via a Zn(OTf $)_{2-}$ catalyzed cascade reaction of anilines with aromatic aldehydes and carbonyl compounds. Tetrahedron, 62: $10079-10086$.

25. Fang, D., Fei, Z. and Liu, Z. L. (2009). Functionalized ionic liquids as the recyclable catalyst for Mannich-type reaction in aqueous media. Catalysis Communications, 10: 1267-1270.

26. Yi, L., Zou, J. H., Lei, H. S. and He, Q. L. (1991). The Mannich reaction of butanone, aromatic aldehydes and aromatic amines. Synthetic Communications, 21:2109-2117.

27. Yi, W. B. and Cai, C. (2006). Mannich-type reactions of aromatic aldehydes, anilines and methyl ketones in fluorous biphase systems created by rare earth (III) perfluorooctane sulfonates catalysts in fluorous media. Journal of Fluorine Chemistry, 127: 1515 - 1521. 